Advances in Gene Technology: The Genome and Beyond -

Structural Biology for Medicine (Proceedings of the 2002 Miami

Nature Biotechnology Winter Symposium)

TheScientificWorld 2002, 2(S2), 125-126

ISSN 1532-2246; DOI 10.1100/tsw.2002.59

\title{
PROCOLLAGEN-LIKE PROTEIN AS A MOLECULAR TARGET IN THE TREATMENT OF PRIMARY BRAIN TUMOR
}

\author{
Medhi Wangpaichitr, Howard Landy, Chun Jing Wu, Lynn G. Feun, Rong Xu, Jenny Xu, and \\ Niramol Savaraj \\ VA Medical Center and Sylvester Comprehensive Cancer Center, Miami FL 33125 \\ medhiw@yahoo.com
}

INTRODUCTION. We have previously reported that the presence of a unique 220-Kd protein, which is recognized by vitamin D receptor (VDR) monoclonal antibody, correlated with vitamin D3 (VD3) sensitivity in primary brain tumor[1]. In this communication we have attempted to further characterize this protein and to investigate how VD3 induces apoptosis in glioma cells.

METHODS. cDNA library was obtained in one glioma cell line which highly expressed this protein and screening was performed using VDR monoclonal antibody. This partial cDNA was then subcloned into pcDNA3.1 and sequencing was performed. This partial cDNA sequence also was used as a probe to identify mRNA, which encodes for this putative gene. To characterize this 220-Kd protein, we have used five cell lines as follows: Glioma 1, U118, SW1783, which possess variable amount of 220-Kd protein, and U-373 and T-98G which lack this 220-Kd protein.

To study the mechanism how VD3 induces apoptosis, we have employed the gene array technique to identify which apoptotic pathway(s) may be involved in this event

RESULTS. We have identified a 2.2-Kb fragment using immunoscreening. This fragment was subsequently sequenced. Via BLAST search through GENBANK, this cDNA fragment was found to be identical to nucleotide 2840-5118 of procollagen alpha 1 type 1 . These nucleotides correspond to the C-terminal of procollagen and $600 \mathrm{bp}$ of 3'untranslated region. It is unclear why VDR monoclonal antibody recognizes the C-terminal of procollagen. To clarify this, we have used the immunoprecipitation technique to investigate whether a VDR monoclonal antibody (obtained from Chemicon) cross reacts with procollagen type 1. Our results indicate that the immunoprecipitant of cell lysate with VDR antibody also reacts with the antibody against the Cterminal peptide of procollagen type 1. Furthermore, immunoblot of cell lysate using antibody against $\mathrm{N}$ - and C-terminal of procollagen type 1 also detected the 220-Kd protein. The signal intensity obtained from the five cell lines also correlates with those obtained using VDR monoclonal antibody.

Using the $1.6 \mathrm{~Kb}$ as a probe, we have performed northernblot analysis on these five cell lines. Our results are shown below. 


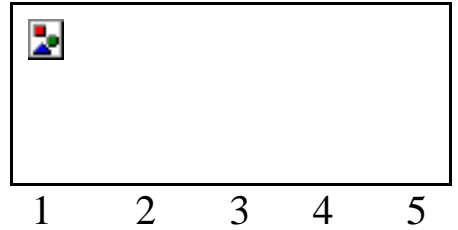

Lane 1: SW1783; Lane 2: Glioma; Lane 3: U118; Lane 4: T98G; Lane 5: U373

This 1.6-Kb fragment hybridized to $5.8-\mathrm{Kb}$ message, which is similar to those reported in the literature for procollagen type 1.

To study how VD3 induced apoptosis in three cell lines, which possess this 220-Kd protein, cDNA was obtained from control as well as from cells after exposure to $10 \mathrm{ng}$ of VD3 for $48 \mathrm{~h}$. This cDNA was labeled with ${ }^{32} \mathrm{dCTP}$ and hybridized with membrane, which contained genes from different signal transduction pathways and apoptosis pathways. These membranes were obtained from SuperArray. Our results indicated that apoptosis might involve caspase-9 but not 3. Inhibitor for caspase 3 also did not inhibit apoptosis.

DISCUSSION. We have previously identified a 220-Kd correlates with VD3 sensitivity. In this report, we have shown that this protein is also recognized by procollagen antibody to both $\mathrm{N}$ - and C-terminal. However, whether this protein is indeed procollagen type 1 or not is still unclear. It has been reported that procollagen type 1 contains two mRNA species at 4.8 and $5.8 \mathrm{~Kb}$, respectively[2,3], thus it is conceivable that the $5.8 \mathrm{~Kb}$ mRNA could be procollagen type 1 . The molecular weight of procollagen alpha 1 type 1 is unclear. An extensive review of the current literature suggests that the molecular weight of this protein varies from $140-210 \mathrm{Kd}$. These differences may represent different mRNA species found in different types of tissues as well as post-translational modification. However, our initial results do not suggest that the 220-Kd protein is glycosylated or phosphorylated. Preliminary data suggest that the putative full length cDNA also possesses sequence which is homologous to the $\mathrm{N}$-terminal of procollagen alpha 1 type 1 , but differences are seen starting from nucleotide 1777-2840. These data need to be confirmed. Nevertheless, the expression of this $220-K d$ protein detected by either RT-PCR or immunoblot using procollagen type 1 antibody or VDR monoclonal antibody strongly correlated with in vitro vitamin D sensitivity. Further work is ongoing in our laboratory to isolate the full-length cDNA and to study its relationship with VD3 sensitivity.

\section{REFERENCES}

1. Zou, J., Landy, H., Feun, L., Xu, R., Limpidis, T., Wu, C.J., Furst, A.J., and Savaraj, N. (2000) J. Biochem. Pharmacol. 60, 1361-1365.

2. $\quad$ Chu, M.L., Wet, W., Bernard, M., and Ramirez, F. (1985) J. Biol. Chem. 260(4), 2315-2320.

3. Tromp, G., Kuivaniemi, H., Stacey, A., Shikata, H., Baldwin, C.T., Jaenisch, R., and Prockop, D.J. (1988) Biochem. J. 253(3), 919-922. 


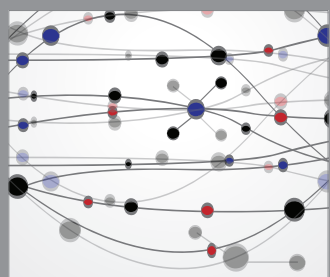

The Scientific World Journal
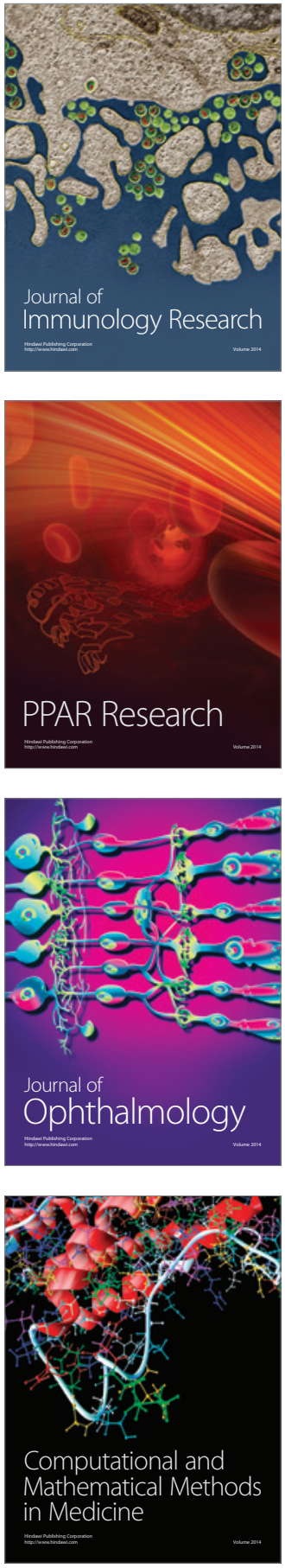

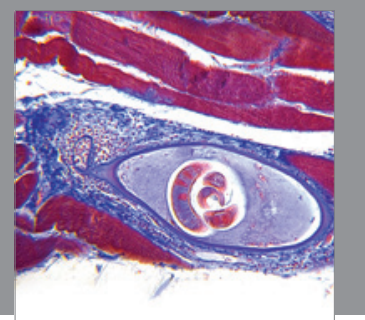

Gastroenterology

Research and Practice
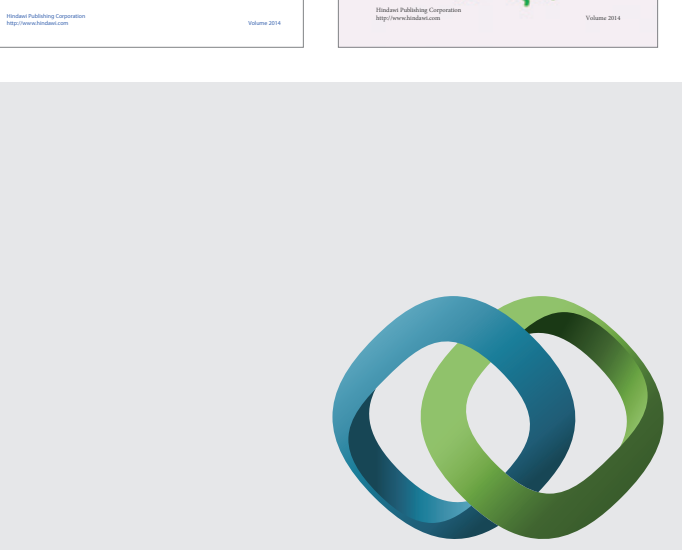

\section{Hindawi}

Submit your manuscripts at

http://www.hindawi.com
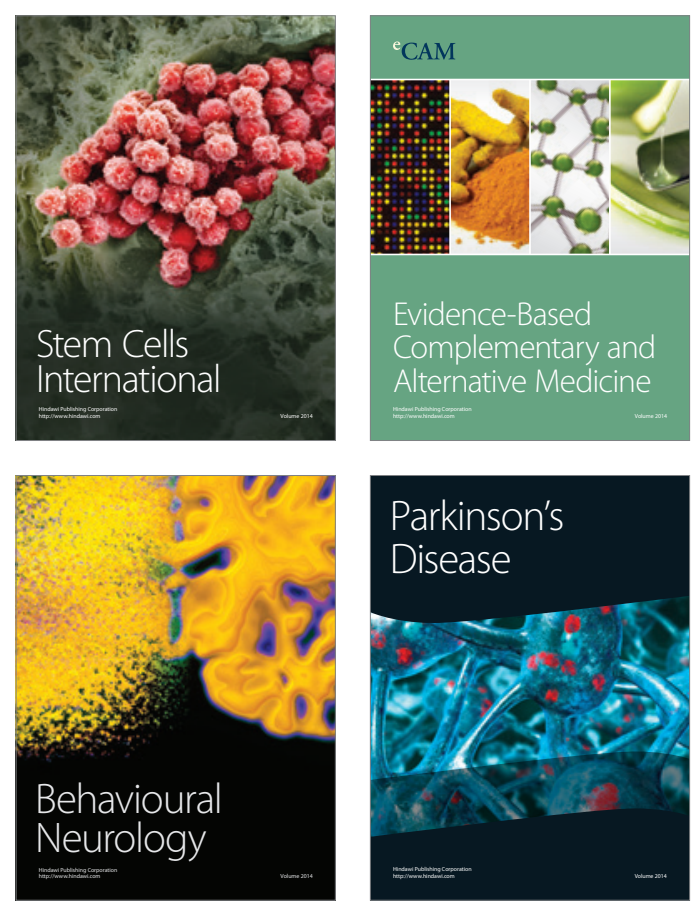

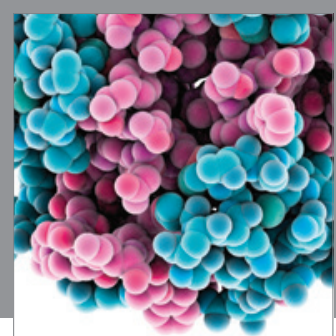

Journal of
Diabetes Research

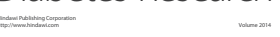

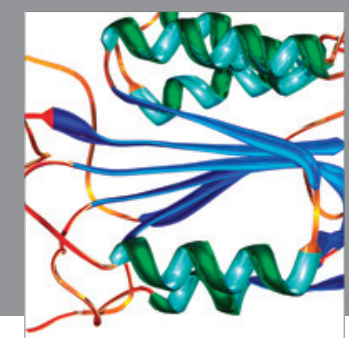

Disease Markers
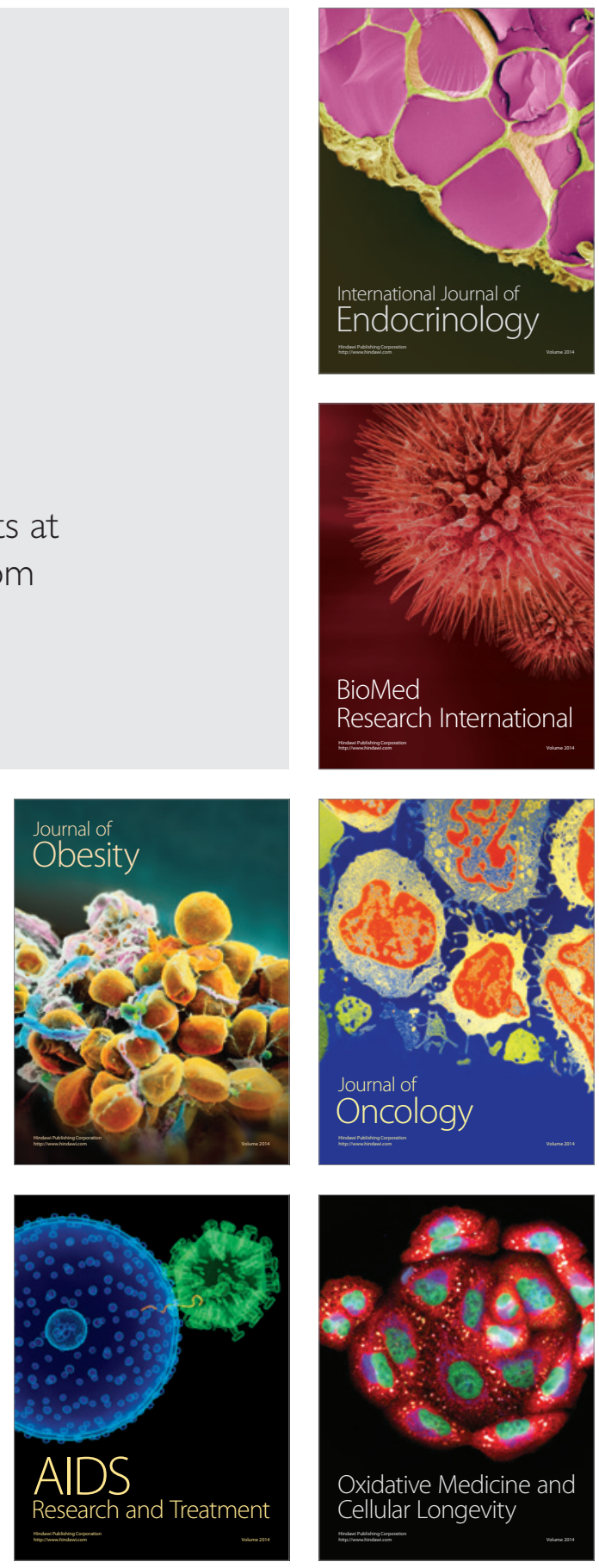